\title{
THE FEATURES OF ADOLESCENTS'S PERCEPTIONS ABOUT PARENTHOOD
}

https://doi.org/10.37096/SHDISJ-20-1.1-0012

Yablonska Tetiana,
ORCID ID: 0000-0001-7272-9691
Bulatevych Nataliya,
ORCID ID: 0000-0002-2971-8740
Maksymchuk Daria,
ORCID ID:0000-0001-5359-7849

Abstract

The relevance of the study of the parenthood perceptions of modern adolescents is determined by decreasing level of paternity readiness among modern youth. The aim of the study is to investigate the features of adolescents' parenthood apprehensions.

The study involved 63 teenagers (37 boys and 26 girls) aged 15 to 17 years. Adolescents' parenthood perceptions were studied with the help of «Ideas of Ideal parenthood» (R.Ovcharova, Yu.Degtyaryova), as well as with the method of «Composition about parenthood»(O.Karabanova, A.Shvedovskaya, modification by S.Abdullina). Such methods as the descriptive statistics, correlation analysis, Student's ttest were used for data analyses.

Parenthood perceptions are considered as an indicative basis for future parenthood readiness. The content and hierarchy of different components of these apprehensions are defined, such as: cognitive, emotional and behavioral.

The content of adolescents' parenthood apprehensions were revealed, including the image of the future child, the image of relationships in the future family, the idea of himself/herself as a parent. In particular, adolescents' perceptions about themselves as future parents were found to be the least represented in the descriptions of the subjects; they are often associated with ambivalent feelings.

Significant differences in the content of adolescents' parenthood apprehensions about ideal parenting were found. Their structure depends on gender: girls' perceptions are wide enough and mostly they are positively emotionally colored, the majority of the boys' perceptions are not formed and often they have neutral, negative or ambivalent emotional coloring. Gender differences in the structure and level of components of parenthood perceptions manifest themselves in the significantly higher level of girls' behavioral and emotional components, as well as in the greater interconnection of the different components of boys' parenthood perceptions.

Keywords: parenthood, parenthood apprehensions, image of future family.

\section{Introduction}

Nowadays the Institute of Family is undergoing changes that some scientists call the crisis of the family, others - its transformation. These processes are particularly noticeable in contemporary
Ukrainian society, burdened by the complex socio-political and economic situation (Yablonska, Bulatevych, \& Mambetova, 2019). First of all, the ordinary families feel the consequences of this situation, in which the family 
"SOCIALIZATION \& HUMAN DEVELOPMENT" INTERNATIONAL JOURNAL

relationship and the upbringing system are broken.

Changes that take place in the family also cause the transformation of ideas about paternity, the emergence of a variety of forms. Along with the fact that the birth of children is a significant human value, in modern world there are a number of unfavorable trends. Thus, statistics shows an increase in cases of deviant paternity, the emergence of orphanage while there are parents (Abdullina, 2018; Zakharova, 2017; Ovcharova, 2005). In general, there is a trend of delaying the birth of a child, paternity is becoming more "late". The reasons for this are the priorities of career development and self-realization, a stable hedonistic orientation of the individual (the desire to enjoy life before raising children), etc. There is the fact that more and more often, after the birth of the child, parents try to distance themselves from the independent realization of parental functions and hand over their children into the hands of helpers. Increasingly, there are couples who, for various reasons, consciously decide to be childless (the socalled "child free") (Zakharova, 2017; Lindsey S., Strutzenberg A., \& Strutzenberg C., 2019).

Studies in this field (Zakharova, 2017; Meshcheriakova, 2002; Ovcharova, 2005; Yablonska, Bulatevych, \& Mambetova, 2019) show a decrease in paternity readiness among modern youth, a decrease in intergenerational interactions in the exercise of parental functions, increasing anxiety associated with ideas about parenthood. Therefore, studying of the peculiarities of ideas of modern children, adolescents and young people about parenthood is relevant and timely.
Purpose of the study - to investigate the features of adolescents' ideas about parenthood.

Research methodology and organization. The study involved 63 adolescents ( 37 boys and 26 girls) between the ages of 15 and 17, students of the 10th and 11th grades of secondary schools in Kyiv.

Adolescents' perceptions of paternity were explored using R. Ovcharova's and Y.Degtyaryova's «Idea of Ideal Parenthood», which is a variant of semantic differential developed on the basis of content analysis of compositions about paternity. The technique includes 54 pairs of qualities, each of which is rated on a 7point scale. In the structure of ideas about paternity, R. Ovcharova distinguishes cognitive, emotional and behavioral components, each of which is calculated in total using 16 pairs of qualities (Ovcharova, 2005).

In addition, the respondents wrote the composition about the future parenthood (author's modification of the method "Parent's composition" by A. Karabanova, A. Shvedovskaya) by S. Abdullina (Abdullina, 2018). The respondents were given blank with unfinished sentences and it was suggested to complete them with the most appropriate phrase or several phrases. The respondent can write whatever he wants, or what he considers important and necessary. The respondent's answers are divided into three meaningful blocks after analyzing the method "Future Parenthood": "The image of the future child", "The image of the relationship in the future family", "Me as a father/mother".

Descriptive statistics, correlation analysis, Student's t-distribution were used for data processing. 
"SOCIALIZATION \& HUMAN DEVELOPMENT" INTERNATIONAL JOURNAL

\section{Theoretical background}

The works on the ontogeny of the parental sphere of the person, note that psychological readiness for paternity goes through a long period of formation through the formation of ideas about paternity, starting from preschool age (Meshcheriakova, 2002; Filippova, 2002; Chan, \& Tam, 2016) Perceptions of parenthood are studied as an indicative basis for future parental readiness (Abdullina, 2018; Zakharova, 2017). The components of the idea of paternity are distinguished in a number of works, such as: value-semantic (sense of parenthood and place in the system of values of personality), cognitive (image of the future child and himself as parents), emotional (emotional attitude to oneself in the parental role) and behavioral (child care skills) (Ovcharova, 2005; Pavlova, 2012).

\section{Results}

An analysis of the results of the «Idea on Ideal Parenthood» methodology showed that the expressiveness of each component of the conception of girls and boys is different. Table 1 provides descriptive statistics for the sample as a whole and separately for the boys and girls groups.

Table 1.The components' expressiveness of ideas about ideal parenthood in adolescent groups $(\mathrm{N}=63)$

\begin{tabular}{|c|c|c|c|c|c|c|}
\hline \multirow{2}{*}{$\begin{array}{c}\text { The } \\
\text { components of } \\
\text { ideas }\end{array}$} & \multicolumn{2}{|c|}{$\begin{array}{c}\text { Boys } \\
\mathbf{N = 3 7 )}\end{array}$} & \multicolumn{2}{c|}{$\begin{array}{c}\text { Girls } \\
(\mathbf{N = 2 6})\end{array}$} & \multicolumn{2}{c|}{$\begin{array}{c}\text { In general, on a sample } \\
(\mathbf{N = 6 3 )}\end{array}$} \\
\cline { 2 - 7 } & Average & $\begin{array}{c}\text { Standard } \\
\text { deviation }\end{array}$ & Average & $\begin{array}{c}\text { Standard } \\
\text { deviation }\end{array}$ & Average & $\begin{array}{c}\text { Standard } \\
\text { deviation }\end{array}$ \\
\hline Cognitive & 11,0 & 12,80 & 16,08 & 7,50 & 13,1 & 11,15 \\
\hline Emotional & 12,08 & 8,38 & 15,96 & 4,86 & 13,7 & 7,35 \\
\hline Behavioral & 14,70 & 9,85 & 41,0 & 21,65 & 17,6 & 9,77 \\
\hline
\end{tabular}

The analysis of girls 'and boys' perceptions about ideal parenthood revealed the similarity in their hierarchy as the components of perceptions were expressed. The behavioral component of apprehensions about ideal parenthood is more expressed; it includes ideas about parents' skills in caring for, supporting, bringing up and teaching a child. In a girls' sample it is followed by a cognitive, then emotional component with the same degree of expression. Instead, boys have emotional component in the second place and cognitive one in the third place. The emotional component includes indicators that describe the subjective experiences of the person in the parental role, parental feelings, and attitudes towards the child, which is demonstrated through the palette of emotions and emotional states. The cognitive component encompasses the perceptions of being father/mother, child's image, parental functions, and more. The dominance of the behavioral component of perceptions may indicate either a greater awareness of adolescents in what the ideal father/mother should do and how they should behave, or their confidence about the most desirable parental behavior for the child. Less expressiveness of the cognitive and emotional component may indicate its less manifestation in adolescents' parents' behavior, and thus - less representation in apprehensions about ideal parenthood.

A correlation analysis was performed to identify significant relationships between the cognitive, 
"SOCIALIZATION \& HUMAN DEVELOPMENT" INTERNATIONAL JOURNAL

emotional, and behavioral components of parenthood perceptions within a sample of adolescent boys and girls (table 2).

Table 2. Pearson's correlation coefficient between components of apprehensions about ideal parenthood

\begin{tabular}{|c|c|c|c|c|}
\hline \multirow{2}{*}{$\begin{array}{l}\text { Components of } \\
\text { apprehensions } \\
\text { about parenthood }\end{array}$} & \multicolumn{2}{|c|}{ Cognitive component } & \multicolumn{2}{|c|}{ Emotional component } \\
\hline & $\begin{array}{l}\text { Girls } \\
\mathrm{N}=26\end{array}$ & $\begin{array}{r}\text { Boys } \\
\mathrm{N}=37 \\
\end{array}$ & $\begin{array}{l}\text { Girls } \\
\mathrm{N}=26\end{array}$ & $\begin{array}{l}\text { Boys } \\
\text { N=37 }\end{array}$ \\
\hline Emotional component & $\begin{array}{c}0,376 \\
\mathrm{p} \leq 0,058\end{array}$ & $\begin{array}{l}0,562 * * \\
\mathrm{p} \leq 0001\end{array}$ & & \\
\hline Behavioral component & $\begin{array}{c}0,234 \\
\mathrm{p} \leq 0,251\end{array}$ & $\begin{array}{c}0.521 * * \\
\mathrm{p} \leq 001\end{array}$ & $\begin{array}{c}0,247 \\
\mathrm{p} \leq 0,224\end{array}$ & $\begin{array}{l}0,649 * * \\
\mathrm{p} \leq 0001\end{array}$ \\
\hline
\end{tabular}

The analysis of the data shows that there are no significant correlations between the components of the apprehensions about ideal parenthood within the group of girls, but instead, there are significant correlations between all components of apprehensions about ideal parenthood within the group of boys. This demonstrates the close connection between the components of boys' apprehensions about ideal parenthood and their interdependence.

The Student's t-test for the independent samples was applied to test the statistical significance of differences in the expressiveness of the components of apprehensions about ideal parenthood in the boys' and girls' samples. The results of the analysis are presented in table 3 .

Table 3. Significance of the differences in expressiveness of components of apprehensions about ideal parenthood

\begin{tabular}{|c|c|c|c|c|c|}
\hline \multirow{2}{*}{$\begin{array}{c}\text { Components of } \\
\text { apprehensions }\end{array}$} & $\begin{array}{c}\text { The Livin's criterion } \\
\text { for equality of } \\
\text { variations }\end{array}$ & t-test & $\begin{array}{c}\text { The } \\
\text { difference in } \\
\text { average }\end{array}$ & $\begin{array}{c}\text { Significance } \\
\text { level }\end{array}$ \\
\cline { 2 - 3 } & $\mathbf{F}$ & Significance & & & \\
\hline Cognitive & 3,494 & 0,07 & $-1,81$ & $-5,08$ & 0,075 \\
\hline Emotional & 2,460 & 0,12 & $-2,12$ & $-3,88$ & 0,038 \\
\hline Behavioral & 0,069 & 0,794 & $-2,947$ & $-6,95$ & 0,005 \\
\hline
\end{tabular}

As table 3 shows, significant differences in the expression of the emotional and behavioral components of perceptions about parenthood among boys and girls were discovered. Thus, girls, unlike boys, understand ideal parents significantly more emotionally involved in the process of interaction with the child, in the educational process, those who have more corresponding parenting skills.
Comparing these results with the correlation analysis data described above, we can assume that boys' apprehensions about parenthood are not only less formed in terms of their behavioral and emotional component, but also less differentiated compared to girls' perceptions.

Differences between girls and boys were also found in the analysis of the results of the composition about future 
parenthood. Thus, $39 \%$ of the respondents demonstrated a positive emotional background of the work, most of whom $(72 \%)$ were girls. Instead, boys dominate in the study groups, where the relationship with the child is described emotionally neutral, ambivalent, negative or not described at all. Thus, the domination of neutral emotional background or the presence of formal responses characterized the compositions of $37 \%$ of respondents, including $78 \%$ of boys and $22 \%$ of girls. An ambivalent description of future parenthood was observed in $5 \%$ of the total sample (66.5\% boys and $33.5 \%$ girls). Negatively colored answers, indicating reluctance to have a baby have the same distribution of responses. The absence of any answers about themselves as a parent and about their future child was found in $14 \%$ of the sample, including $89 \%$ boys and only $11 \%$ girls.

All discovered differences in perceptions about parenthood are expected, but their nature causes anxiety in the context of preparing young people for parenthood. Yes, it can be expected that the poverty, the narrowing of the boys' apprehensions about parenthood, which also have a negative emotional coloring, can cause further difficulties in accepting the role of the father.

Analysis of the exact meaning blocks of the «Composition about future parenthood» gives an opportunity to analyze the content of modern adolescents' perceptions about parenthood. The apprehensions about future child include a description of their hobbies, expected personal traits (both positive from a teenager's point of view and negative ones), and concerns about the child. Among the apprehensions about a future child's hobbies, on the first place are the statements about the child's ability to choose what he likes, ability to dedicate time to his own wishes. The second position is divided between training and sports. A complete list of apprehensions about child's hobbies is presented in table 4.

Table 4. Rating of characteristics of the future child by the results of the analysis of "Composition about parenthood"

\begin{tabular}{|c|c|c|c|}
\hline Child's interests & Positive qualities of a child & $\begin{array}{l}\text { Negative qualities } \\
\text { of a child }\end{array}$ & $\begin{array}{l}\text { The biggest fears } \\
\text { about the child }\end{array}$ \\
\hline $\begin{array}{l}\text { 1) A child should } \\
\text { choose his own } \\
\text { hobbies and } \\
\text { interests } \\
\text { 2) Education. } \\
\text { Sport } \\
\text { 3) Communication } \\
\text { with his/her } \\
\text { family and } \\
\text { friends } \\
\text { 4) Creativity } \\
\text { 5) Learning } \\
\text { foreign } \\
\text { languages; Self } \\
\text { development }\end{array}$ & $\begin{array}{l}\text { 1) A sense of happiness } \\
\text { 2) Kindness } \\
\text { 3) Mind } \\
\text { 4) Purposefulness, success, } \\
\text { confidence, diligence } \\
\text { 5) Communication skills, } \\
\text { openess, friendlyness } \\
\text { 6) Culture, manners, politeness } \\
\text { 7) Sincerity, honesty } \\
\text { 8) Joy, cheerfulness, sense of } \\
\text { humor } \\
\text { 9) Autonomy } \\
\text { independence } \\
\text { 10) Ability to stand up for } \\
\text { themselves } \\
\text { 11) Determination, courage }\end{array}$ & $\begin{array}{l}\text { 1) Disobedience } \\
\text { 2)Selfishness, } \\
\text { laziness } \\
\text { 3) Failure to study, } \\
\text { closing in } \\
\text { themselves, } \\
\text { falsehood } \\
\text { indifference }\end{array}$ & $\begin{array}{l}\text { 1) Drug addiction, } \\
\text { alcoholism, } \\
\text { smoking, } \\
\text { friendship with } \\
\text { "bad company" } \\
\text { 2) Diseases } \\
\text { 3) Homosexuality }\end{array}$ \\
\hline
\end{tabular}



12) Responsibility
13) Humanity
14) Restraint, peace, depth
15) Adequacy

As we can see from the table 4, among the desirable personal characteristics of the future child, the feeling of happiness is most commonly named. Kindness is next in importance, and in the third place is mind. In general, the number of positive traits is much greater than the number of negative traits of the future child, as well as the future probable problems, which are associated with it (Table 4). Probable drug addiction, alcoholism, smoking, friendship with a "bad company" are the biggest concerns about their future child among teenagers. Possible diseases are on the second place.
And several male respondents expressed fears about their child's homosexuality.

The analysis of apprehensions about relationships with children in the future family shows that most of the respondents want to see them as good, friendly, trusting, sincere, open and loved. Several respondents have noted that they wished to have relationship with their future child not similar to those, which they have with their own families, or they want it to be better. Also some single characteristics - such as equal and free, soft and understanding, warm, harmonious were also named.

Table 5. Rating of perceptions about relationships in the future family and joint affairs with the child

\begin{tabular}{|l|l|}
\hline \multicolumn{1}{|c|}{$\begin{array}{c}\text { Perceptions about relationships in the future } \\
\text { family }\end{array}$} & Joint affairs \\
\hline 1) Good & 2) Spending time together \\
2) Friendly & 3) Walking \\
3) Trusting & \\
4) Normal & \\
5) Not like with their own parents & \\
\hline
\end{tabular}

Among joint affairs with their future child young people generally speak about spending time together without any specific activities. Also, among the common activities they name conversations with child, namely sharing secrets, talking honestly, and sharing everything as if they are friends. Walking is also an important common activity. Rarely answers are: to play together, to have common interests, to do one thing, to travel, to spend evenings together, to play sports.
$92 \%$ of the respondents emphasize the importance of friendly, trusting, open relationships with the child, they point how important a respect is for each other and understanding. It is also important that the child should not be ashamed of his parents, a child should be proud of them.

Regarding the description of themselves as a future father / future mother, the lowest number of respondents' responses was recorded here. Some respondents point out that they feel happiness and pride when they are thinking about a future baby, they are dreaming of 
several children and a strong family. Available descriptions often also reflect fears and anxieties about potential parenthood, marking their incompetence, fears of failing to cope with the role of "good father" or "good mother", and feeling that they will not be able to find a common language with their child. But many teenagers respond that they do not even think about future parenthood.

\section{Disscusion}

According to the researchers, during adolescence period there is a certain duality of the parent sphere and ideas about themselves as a father / mother. (Ovcharova, 2005; Filippova, 2002). On the one hand, researches show the high value of family for young people of 14-18 years, at the same level with the value of "love" and "health". $72.5 \%$ of respondents choose family as the most important value, which indicates its priority in the structure of young people's vital values. But, on the other hand, some teenagers express a bright negativity about future family life. Researches show that they often have an uncertain, sometimes neglectful, type of parental position. They have incomplete knowledge of importance and necessity to take into account such areas of parenthood as the personal qualities of parents; skills and practice of upbringing, knowledge about patterns of development of the child; the image of father/mother can be not sufficiently balanced about the components of parenthood (cognitive, emotional, behavioral). Many adolescents can be characterized by the lack of selfconfidence; partial acceptance of themselves; uncertainty in others evaluation of themselves; they need support from others. They usually have unformed goals of their lives or they can have some manifestations of situational activity or passive anticipation of the situation.

The findings from our study on the structure of parenthood apprehensions among adolescent boys partially correlate with the study of Petrosiants V.R. and Lytkina P.E. (Petrosiants, \& Lytkina, 2017), who studied ideas of young men of 18-23 years old. Scientists note that the brightest is the behavioral component of parenthood apprehensions. The second place takes the cognitive component; and the last is the emotional one.

Comparing the results, which were received by the method "The composition about parenthood" with the study by S.A. Abdullina, it can be stated that people that were interviewed show more responses with positive emotional background of composition (39\% vs. 16.1\%), neutral background (37\% vs. $17.7 \%$ ), and also the major number of composition with negative emotional background (5\% vs. 1.6\%) (Abdullina, 2018). Besides, 5\% of the compositions, which were received in our study, have an ambivalent emotional background; this category of answers in the Abdullina's study is not presented. Comparison of the rating of characteristics of the future child shows that the list of qualities, which were named by young people, corresponds with each other in both studies. Thus, Russian teenagers note the following (in order of decreasing frequency) as: kindness, mind, independence, beauty, success, purposefulness, health, friendliness, happiness, individuality, sensitiveness, respectability, honesty, modesty, manners, and talent. However, their answers do not present the negative characteristics of the future child, as it is presented in our study. But the adolescent's vision about hobbies of their future child slightly differs: 
therefore, the first place in our study takes the answer "the child should choose his/her own hobbies"(see table 4). But in Abdullina's study there is no such answer, which probably reflects an orientation to the democratic style of upbringing.

\section{Conclusion}

As a result of the research, the features of adolescent's apprehension about future paternity were revealed, particularly, the content and representation of the cognitive, emotional and behavioral components of these ideas among boys and girls. It was found that the hierarchy of representation of main conceptions among young boys and girls is similar with dominance of the behavioral component. This can point out the greater awareness about parent's skills and competences, compared to the representation of the child's image and feelings related to the parental role.

Also gender differences in the structure and level of expression of main conceptions of paternity were revealed. Therefore, if we compare boys versus girls, the components of the concept are interrelated, interdependent. Girls have a significantly higher level of formation of the behavioral and emotional component of ideas. This can prove that these conceptions about future parenthood will help them to be more emotionally involved parents into the process of interaction with the child and into the educational process, those who will have better parenting skills.

The content of teenager's perceptions of parenthood was revealed, especially the image of their future child and the image of relationships in the future family, and their own perceptions about themselves as future mother/father. It was revealed that adolescent's perceptions about themselves as future mother/father are least represented in the descriptions of respondents. They are often associated with ambivalent feelings, either reflecting joy and pride when thinking about having a baby, or fears about potential parenthood. Teenagers often worry about their own incompetence. They fear not to be able to cope with the roles of "good mother" or "good father."

Significant differences were found in the content of adolescent's perceptions of ideal parenting, their structure, depending on gender: if these ideas are quite often for girls, and mostly often they are positively emotionally colored, then most of the boys have not formed ideas and often they have a neutral, ambivalent, or negative emotional color.

The prospect of further research is to examine the relationship between teenagers' perceptions of parenthood with the nature of the child-parent relationship, as well as developing psycho-educational and psycho-corrective programs, aimed either at optimizing real child-parent relationships, or at correcting teenagers' stereotypical perceptions of family and parenthood.

\section{References}

Abdullina, S.A. (2018) Predstavlenyia o rodytelstve u detei doshkolnoho, mladsheho shkolnoho i podrostkovoho vozrasta (Dys. kand. psykhol. nauk). Avtonomnaia nekommercheskaia orhanyzatsyia vyssheho obrazovanyia "Moskovskyi humanytarnyi uniersytet". [Parenthood apprehensions in preschool children of primary school and adolescence]. Moscow. (Russian)

Zakharova E.Y. (2017) Rodytelstvo kak vozrastno-psykholohycheskyi 
fenomen (Dys. dokt. psykhol. nauk) [Parenthood as an age-psychological phenomenon].

Moskovskyi hosudarstvennyi universytet im. M.V.Lomonosova. Moscow. (Russian)

Meshcheriakova, S.Yu. (2002) Put k materynstvu nachynaetsia $\mathrm{s}$ mladenchestva. [The path to motherhood begins with infancy] Doshkolnoe vospytanye, 11, 81-89. (Russian)

Ovcharova, R.V. (2005) Psykholohyia rodytelstva [Psychology of Parenthood]. Moscow: Yzd-vo: Akademyia. (Russian)

Pavlova, T.V. (2012) Psykholohycheskie determynanty formirovania predstavlenyi lichnosti o roditelstve (Dys. kand. psykhol. nauk) [Psychological determinants of the formation of the person's ideas about parenthood]. Rossyiskyi unyversytet druzhby narodov. Moscow. (Russian)

Petrosiants, V.R., Lytkina, P.E. (2017) Struktura predstavlenyi ob idealnom roditele u yunoshei-studentov VUZa [The structure of apprehensions about the ideal parent of young students of the university]. Universum: Psykholohyia y obrazovanie: elektron. nauchn. zhurn. 2(32). URL: $\mathrm{http} / / / 7$ universum.com/ru/psy/archiv e/item/4286 (дата обращения: 18.03.2020).

Filippova, H.H. (2002) Psykholohyia materynstva: uchebnoe posobie. [The Psychology of Maternity: A Study Guide]. Moscow: Izd-vo Instytuta psykhoterapii. (Russian)

Yablonska, T. M., Bulatevych, N. M., Mambetova, A. A. (2019) Obrazy idealnykh batkiv yak skladova chastyna uiavlen pro batkivstvo $\mathrm{v}$ yunatskomu vitsi: etnopsykholohichni osoblyvosti. [The images of ideal parents as a component of apprehensions of parenthood in the youth: ethnopsychological features]. Teoriia $i$ praktyka suchasnoi psykholohii, 6(2), 142-147. DOI https://doi.org/10.32840/26636026.2019.6-2.25 (Ukrainian)

Chan, H.W., Tam, K.P. (2016) Understanding the Lack of ParentChild Value Similarity. The Role of Perceived Norms in Value Socialization in the Immigrant Families. Cross-cultural Psychology, 47(5), 651-669. DOI: 10.1177/0022022116635744

Lindsey, S. Aloia \& Claire Strutzenberg (2019)

Parent-Child Communication Apprehension: The Role of Parental Alienation and SelfEsteem. Communication Reports, 32 (1), 1-14. DOI: $\underline{10.1080 / 08934215.2018 .1514641}$ 